\title{
ORGANIC AMENDMENTS FOR MITIGATING SOIL SALINITY IN RICE
}

\author{
Shithi Chowdhury, Dhiman Bhusan, Md. Abul Hashem and Md. Anamul Hoque* \\ Department of Soil Science, Faculty of Agriculture, Bangladesh Agricultural University, \\ Mymensingh-2202, Bangladesh.
}

*Corresponding author: Md. Anamul Hoque; E-mail: anamul71@bau.edu.bd

\begin{abstract}
ARTICLE INFO
A B S T R A C T

Received

01 March, 2019

Accepted

20 April, 2019

Online

30 April, 2019

Key words:

Farmyard manure

Poultry manure

Salt stress

Rice

Salinity causes cellular damage and limits crop productivity. Accumulation of organic compound is one of the adaptive mechanisms to salinity in plants. The experiments were laid out in a randomized complete block design with three replications at the farmer's field of Botiaghata, Khulna to investigate the mitigating effects of organic manures on salinity stress in rice genotypes during both aman and boro seasons. Two T. aman rice (salt-sensitive; BR-23 and local cultivar; Mohini) and two boro rice (salt-sensitive; BRRI dhan-29 and salt-tolerant; BINA dhan-8) were used as test crops. Farmyard manure (FYM) and poultry manure (PM) were applied to the soils during final land preparation. There were five treatments namely $T_{0}=$ control (no manure), $T_{1}=F Y M(5 t / h a), T_{2}=F Y M(10 t / h a), T_{3}=P M(4 t / h a), T_{4}=P M(8 t / h a)$. Thirtyday-old rice seedlings were transplanted in the experimental plots. Salinity caused a significant reduction in growth and yield of both aman and boro rice. Under saline condition, BR-23 (aman rice) produced higher yield than local cultivar Mohini in aman season while BINA dhan-8 produced higher yield than BRRI dhan29 in boro season. Soil amendments with FYM and PM significantly increased the growth, and grain and straw yields of all rice cultivars under saline conditions. Increased nutrient uptake and $\mathrm{K}^{+} / \mathrm{Na}^{+}$ratio in rice were also observed due to application of organic manures. No considerable changes in post-harvest soil properties such as $\mathrm{pH}, \mathrm{EC}, \mathrm{CEC}$ and organic matter status of saline soils were observed by addition of FYM and PM. The present study suggests that soil amendments with FYM and PM improve salt tolerance in rice by increasing $\mathrm{K}^{+} / \mathrm{Na}^{+}$ratio and nutrient uptake.
\end{abstract}

To cite this article: Chowdhury S, D. Bhusan, M. A. Hashem and M. A. Hoque, 2019. Organic amendments for mitigating soil salinity in rice. Res. Agric. Livest. Fish. 6 (1): 11-17. 


\section{INTRODUCTION}

Soil salinity is a major concern to agriculture all over the world because it affects almost all plant functions. Millions of hectares of land throughout the world are too saline to produce economic crops, and more land is becoming non-productive each year due to salinity build up. Approximately $7 \%$ of the world's land area, $20 \%$ of the world's cultivated land and nearly half of the irrigated land are affected by soil salinity (Zhu, 2001; FAO, 2008; Mali et al., 2012). In view of another projection, $2.1 \%$ of the global dry land agriculture is affected by salinity (FAO, 2008). The world population is increasing rapidly and may reach 6 to 9.3 billion by the year 2050 whereas the crop production is decreasing rapidly because of the negative impact of various environmental stresses; therefore, it is now very important to develop stress-tolerant varieties to cope with this upcoming problem of food security. In addition, increased salinity of arable land is expected to have devastating global effects, resulting in up to $50 \%$ land losses by the middle of the twenty-first century (Mahajan and Tuteja, 2005). Agriculture is the most important sector of Bangladesh's economy. Usually $30-50 \%$ yield losses occur depending on the level of soil salinity. Over $30 \%$ of the cultivable area of Bangladesh lies in the coastal and offshore zones. Out of 2.86 million hectares of coastal and offshore lands, about 1.06 million hectares are affected by varying degrees of salinity (SRDI, 2010). The area under salinity is increasing with time (from 0.83 $\mathrm{m}$ ha to $1.056 \mathrm{~m}$ ha in 36 years; SRDI, 2010) due to rise in sea water level with increased global temperature. These coastal saline soils are distributed unevenly in 64 upazilas of 13 coastal districts covering portions of 8 agro-ecological zones of the country. Increased soil salinity due to climate change would significantly reduce food grain production. However, about $20 \%$ peoples of Bangladesh are seriously affected by soil and water salinity in the coastal belt. Transplated aman rice is mainly grown in the saline areas but the yield is very low due to lack of salt-tolerant high yielding variety and inappropriate management practices. According to the IPCC (2007), crop production may fall by $10-30 \%$ by 2050 in Bangladesh due to climate change. Salt stress increases the accumulation of toxic ions such as $\mathrm{Na}^{+}$and $\mathrm{Cl}^{-}$in different plant parts, tissues, cells and cell organelles. Accumulation of excess $\mathrm{Na}^{+}$and $\mathrm{Cl}^{-}$causes ionic imbalances that may impair the selectivity of root membranes and induce potassium deficiency (Gadallah, 1999). Excess $\mathrm{Na}^{+}$and $\mathrm{Cl}^{-}$lead to the appearance of symptoms like $\mathrm{K}^{+}$deficiency. The deficiency of $\mathrm{K}^{+}$initially leads to chlorosis and then causes necrosis (Gopal and Dube, 2003).

Soil salinization is a major process of land degradation that decreases soil fertility and crop productivity. There is a report that coastal regions of Bangladesh are quite lower in soil fertility (Haque, 2006; Kibria et al., 2015). Appropriate management strategies and techniques with suitable crop genotypes having higher yield potential could contribute to the improvement of crop production in the coastal areas of Bangladesh. Both organic and inorganic amendments are found to be effective in the amelioration of saline soils. The best means of maintaining soil fertility, productivity and salt tolerance could be through addition of organic manures. Various organic amendments such as farmyard manure, compost, poultry manure and mulch can be used for the amelioration of saline soils. Organic amendments improve physical, chemical and biological properties of soils under saline conditions. There are evidences that soil amendments with organic manures reduce the toxic effects of salinity in various plant species (Idrees et al., 2004; Abou El-Magd et al., 2008; Leithy et al., 2010; Raafat and Thawrat, 2011). Soil salinity management did not receive proper attention in the past, but now emphasis has been given on this issue. Sustainable and profitable productions of crops in salt-affected areas are possible if appropriate soil management is made. There is no systematic information in Bangladesh about the role of organic amendments in the mitigation of salinity in crop cultivation.

\section{MATERIALS AND METHODS}

\section{Experimental site and soils}

The experiments were carried out at the farmer's field of Botiaghata, Khulna belongs to the Agroecological Zone of the Ganges Tidal Floodplain (AEZ 13). Characteristically, the soil was silty clay loam having $\mathrm{pH}$ 6.7-7.2, EC 4.6-6.6 dS/m, CEC $23-26 \mathrm{meq} / 100 \mathrm{~g}$ soil and organic matter $0.71-0.84 \%$. The experimental area is included into the tropical monsoon climate. There are three monsoon periods appear in this region. The monsoon period lasts from May to October. About $88 \%$ of the total rainfall is observed in this time. Hailstone also occurs during this time. Sometimes storms locally called Kalboishakhi are observed. 


\section{Plant materials and treatments}

The experiment was laid out in a randomized complete block design (RCBD) with three replications. Two rice cultivars; BR-23 and local cultivar Mohini were used in aman season while BRRI dhan29 and BINA dhan8 rice were used in boro season as test crops in the experiments. The treatments consisted with control and two doses of FYM and PM. There were five treatments namely $T_{0}=$ control (no manure), $T_{1}=F Y M(5 t / h a)$, $\mathrm{T}_{2}=\mathrm{FYM}(10 \mathrm{t} / \mathrm{ha}), \mathrm{T}_{3}=\mathrm{PM}(4 \mathrm{t} / \mathrm{ha})$, and $\mathrm{T}_{4}=\mathrm{PM}$ (8 t/ha). Recommended doses of TSP, MoP, gypsum, and zinc sulphate were applied to all the experimental plots during final land preparation. Recommended dose of urea was applied in three splits. Thirty-day-old seedlings of four rice varieties were transplanted in the experimental plots. Three seedlings per hill were placed at a spacing of $25 \mathrm{~cm} \times 20 \mathrm{~cm}$. Water salinity was monitored during the whole period of crop cultivation. Water salinity during aman rice was $4.2 \mathrm{dS} / \mathrm{m}, 2.0 \mathrm{dS} / \mathrm{m}$ and $2.1 \mathrm{dS} / \mathrm{m}$ at seedling stage, tillering stage and panicle initiation stage, respectively. Water salinity during boro rice was 3.2 $\mathrm{dS} / \mathrm{m}, 9.4 \mathrm{dS} / \mathrm{m}$ and $13.8 \mathrm{dS} / \mathrm{m}$ at seedling stage, tillering stage and panicle initiation stage, respectively. Other intercultural operations were done when necessary. The crop was harvested at full maturity. Maturity of crop was determined when about $90 \%$ grains became golden yellow. Grain and straw yields and plant parameters were recorded.

\section{Chemical analysis of plant samples}

The representative grain and straw samples were dried in an oven at $65^{\circ} \mathrm{C}$ for about 24 hours before they were ground by a grinding machine. The prepared samples were stored in paper bags and finally kept into desiccators until analysis. The N, P, K, S and $\mathrm{Na}$ contents from grain and straw samples were determined following standard method as described by Khanam et al. (2001).

\section{Statistical analysis}

Data were analyzed statistically using analysis of variance with the help of software package MSTAT-C. The significant differences between mean values were compared by Duncan's Multiple Range Test. Differences at $P \leq 0.05$ were considered significant.

\section{RESULTS AND DISCUSSION}

\section{Growth and yield components of rice}

Soil salinity caused a significant decrease in plant height of four rice varieties viz. BR-23, Mohini, BRRI dhan29 and BINA dhan-8. Application of organic manures increased the plant height of four rice varieties under saline condition (Tables 1, 2, 3 and 4). Salinity significantly decreased effective tillers hill ${ }^{-1}$ of four rice varieties viz. BR-23, Mohini rice, BRRI dhan29 and BINA dhan-8 (Tables 1, 2, 3 and 4). Application of organic manures did not show significant increase in number of effective tillers of all rice cultivars. It was observed that there were no significant variations in panicle length of four rice varieties viz. BR-23, Mohini, BRRI dhan29 and BINA dhan-8 among the organic amendments. Plants exposed to salinity decreased the number of filled grains panicle ${ }^{-1}$ of four rice varieties (Tables 1, 2, 3 and 4). It was observed that number of filled grains panicle1 in all varieties was significantly increased due to organic amendments under salinity condition. The 1000grain weight of all the varieties was also significantly decreased due to salinity (Tables 1, 2, 3 and 4). Application of organic manures increased 1000-grain weight but there were no significant differences among them.

Islam et al. (2011) on hybrid rice and Miah et al. (1992) on two rice varieties also found that plant growth decreased with increasing salinity. Leithy et al. (2010) on peanut, Abou El-Magd et al. (2008) on sweet funnel and Raafat and Tharwat (2011) on rice have shown that organic amendments increased plant growth at different levels of soil salinity. Abou El-Magd et al. (2008) on sweet funnel, Raafat and Tharwat (2011) and Shazia et al. (2004) on sugarcane also showed that organic amendments increased 1000 grains weight on different salt stress conditions. Momayezi et al. (2010) showed that number of effective tillers per hill was decreased by increasing salinity levels in rice. 
Table 1. Effect of organic manures on growth and yield components of BR-23 rice under saline conditions

\begin{tabular}{|llllll|}
\hline Treatment & $\begin{array}{l}\text { Plant height } \\
(\mathbf{c m})\end{array}$ & $\begin{array}{l}\text { No. of effective } \\
\text { tillers hill }\end{array}$ & $\begin{array}{l}\text { Panicle length } \\
(\mathbf{c m})\end{array}$ & $\begin{array}{l}\text { No. of filled } \\
\text { grains panicle }^{-1}\end{array}$ & $\begin{array}{l}\text { 1000-grain } \\
\text { weight }\end{array}$ \\
& $(\mathbf{g m})$
\end{tabular}

Same letter in a column represents insignificant difference at $p<0.05$.

$\mathrm{SE}=\mathrm{Standard}$ errors of means, $\mathrm{CV}=\mathrm{Co}$-efficient of variation, $\mathrm{NS}=$ Non significant.

Table 2. Effect of organic manures on growth and yield components of Mohini rice under saline condition

\begin{tabular}{|c|c|c|c|c|c|}
\hline Treatment & $\begin{array}{l}\text { Plant height } \\
\text { (cm) }\end{array}$ & $\begin{array}{l}\text { No. of effective } \\
\text { tillers hill }^{-1}\end{array}$ & $\begin{array}{l}\text { Panicle length } \\
\text { (cm) }\end{array}$ & $\begin{array}{l}\text { No. of filled } \\
\text { grains Panicle }{ }^{-1}\end{array}$ & $\begin{array}{l}\text { 1000-grain } \\
\text { weight (gm) }\end{array}$ \\
\hline $\mathrm{T}_{0^{-}}=$Control & $157 b$ & 13 & $25 b$ & $98 b$ & $27.91 b$ \\
\hline $\mathrm{T}_{1}=\mathrm{FYM}\left(5 \mathrm{tha}^{-1}\right)$ & $163 a$ & 14 & $27 a$ & $103 b$ & $28.80 \mathrm{a}$ \\
\hline$T_{2}=F Y M\left(10 t^{h a^{-1}}\right)$ & $162 a$ & 14 & $26 a b$ & $104 b$ & $28.82 a$ \\
\hline $\mathrm{T}_{3}=\mathrm{PM}\left(4 \mathrm{tha}^{-1}\right)$ & $166 a$ & 14 & $26 a b$ & $114 a$ & $28.78 a$ \\
\hline $\mathrm{T}_{4^{-}}=\mathrm{PM}\left(8 \mathrm{th \textrm {ha } ^ { - 1 }}\right)$ & $166 a$ & 15 & $27 a$ & $116 a$ & $28.74 a$ \\
\hline $\mathrm{SE}( \pm)$ & 2.34 & NS & 0.42 & 2.20 & 0.28 \\
\hline $\mathrm{CV}(\%)$ & 2.48 & 5.02 & 2.97 & 3.94 & 3.56 \\
\hline
\end{tabular}

Same letter in a column represents insignificant difference at $p<0.05$.

$\mathrm{SE}=\mathrm{Standard}$ errors of means, $\mathrm{CV}=\mathrm{Co}$-efficient of variation, NS=Non significant.

Table 3. Effect of organic manures on growth and yield components of BRRI dhan-29 under saline conditions

\begin{tabular}{|llllll|}
\hline Treatment & $\begin{array}{l}\text { Plant height } \\
\text { (cm) }\end{array}$ & $\begin{array}{l}\text { No. of effective } \\
\text { tillers hill-1 }\end{array}$ & $\begin{array}{l}\text { Panicle length } \\
\text { (cm) }\end{array}$ & $\begin{array}{l}\text { No. of filled } \\
\text { grains Panicle-1 }^{-1}\end{array}$ & $\begin{array}{l}\text { 1000-grain } \\
\text { weight (gm) }\end{array}$ \\
\hline $\mathrm{T}_{0}=$ Control & $94.27 \mathrm{~b}$ & $14 \mathrm{~b}$ & 25.35 & $94 \mathrm{c}$ & 18.40 \\
$\mathrm{~T}_{1}=$ FYM $\left(5 \mathrm{t} \mathrm{ha}^{-1}\right)$ & $97.27 \mathrm{a}$ & $17 \mathrm{a}$ & 25.90 & $104 \mathrm{~b}$ & 18.76 \\
$\mathrm{~T}_{2}=$ FYM $\left(10 \mathrm{t} \mathrm{ha}^{-1}\right)$ & $97.53 \mathrm{a}$ & $18 \mathrm{a}$ & 25.91 & $109 \mathrm{ab}$ & 19.00 \\
$\mathrm{~T}_{3}=$ PM $\left(4 \mathrm{t} \mathrm{ha}^{-1}\right)$ & $97.60 \mathrm{a}$ & $18 \mathrm{a}$ & 25.87 & $107 \mathrm{ab}$ & 19.02 \\
$\mathrm{~T}_{4}=\mathrm{PM}\left(8 \mathrm{t} \mathrm{ha}^{-1}\right)$ & $97.53 \mathrm{a}$ & $18 \mathrm{a}$ & 25.62 & $111 \mathrm{a}$ & 18.60 \\
$\mathrm{SE}( \pm)$ & 1.20 & 1.12 & $\mathrm{NS}$ & 2.65 & $\mathrm{NS}$ \\
$\mathrm{CV}(\%)$ & 3.22 & 2.50 & 3.27 & 4.45 & 4.25 \\
\hline
\end{tabular}

Same letter in a column represents insignificant difference at $p<0.05$.

$\mathrm{SE}=\mathrm{Standard}$ errors of means, $\mathrm{CV}=\mathrm{Co}$-efficient of variation, NS=Non significant. 
Table 4. Effect of organic manures on growth and yield components of BINA dhan-8 under saline conditions

\begin{tabular}{|llllll|}
\hline Treatment & $\begin{array}{l}\text { Plant height } \\
\text { (cm) }\end{array}$ & $\begin{array}{l}\text { No. of effective } \\
\text { tillers hill }\end{array}$ & $\begin{array}{l}\text { Panicle length } \\
\text { (cm) }\end{array}$ & $\begin{array}{l}\text { No. of filled grains } \\
\text { Panicle }^{-1}\end{array}$ & $\begin{array}{l}\text { 1000-grain } \\
\text { weight (gm) }\end{array}$ \\
\hline $\mathrm{T}_{0}=$ Control & $88.93 \mathrm{~b}$ & $17 \mathrm{~b}$ & $23.83 \mathrm{~b}$ & $98 \mathrm{c}$ & $24.02 \mathrm{~b}$ \\
$\mathrm{~T}_{1}=\mathrm{FYM}\left(5 \mathrm{t} \mathrm{ha}^{-1}\right)$ & $91.40 \mathrm{a}$ & $19 \mathrm{a}$ & $24.47 \mathrm{ab}$ & $112 \mathrm{~b}$ & $26.08 \mathrm{a}$ \\
$\mathrm{T}_{2}=\mathrm{FYM}\left(10 \mathrm{t} \mathrm{ha}^{-1}\right)$ & $93.47 \mathrm{a}$ & $19 \mathrm{a}$ & $24.54 \mathrm{ab}$ & $115 \mathrm{ab}$ & $25.78 \mathrm{a}$ \\
$\mathrm{T}_{3}=\mathrm{PM}\left(4 \mathrm{t} \mathrm{ha}^{-1}\right)$ & $91.73 \mathrm{a}$ & $19 \mathrm{a}$ & $25.84 \mathrm{a}$ & $115 \mathrm{ab}$ & $25.94 \mathrm{a}$ \\
$\mathrm{T}_{4}=\mathrm{PM}\left(8 \mathrm{t} \mathrm{ha}^{-1}\right)$ & $92.20 \mathrm{a}$ & $20 \mathrm{a}$ & $24.46 \mathrm{ab}$ & $122 \mathrm{a}$ & $25.44 \mathrm{a}$ \\
$\mathrm{SE}( \pm)$ & 1.30 & 0.58 & 0.53 & 3.36 & 0.46 \\
$\mathrm{CV}(\%)$ & 2.54 & 1.65 & 2.22 & 4.25 & 1.24 \\
\hline
\end{tabular}

Same letter in a column represents insignificant difference at $p<0.05$.

$\mathrm{SE}=\mathrm{Standard}$ error of means, $\mathrm{CV}=\mathrm{Co}$-efficient of variation.

Table 5. Effect of organic manures on the grain and straw yields of BR-23 and Mohini rice under saline condition

\begin{tabular}{|lllll|}
\hline Treatment & BR-23 & Mohini \\
\cline { 2 - 5 } & Grain yield $\left(\mathbf{k g ~ h a} \mathbf{-}^{-1}\right)$ & Straw yield $\left(\mathbf{k g ~ h a}^{-1}\right)$ & Grain yield $\left.\mathbf{( k g ~ h a}^{-1}\right)$ & Straw yield (kg ha-1 $)$ \\
\hline $\mathrm{T}_{0}=$ Control & $4672 \mathrm{c}$ & $5063 \mathrm{c}$ & $2420 \mathrm{c}$ & $3102 \mathrm{c}$ \\
$\mathrm{T}_{1}=\mathrm{FYM}\left(5 \mathrm{t} \mathrm{ha}^{-1}\right)$ & $5194 \mathrm{~b}$ & $5728 \mathrm{ab}$ & $2616 \mathrm{~b}$ & $3533 \mathrm{~b}$ \\
$\mathrm{~T}_{2}=\mathrm{FYM}\left(10 \mathrm{t} \mathrm{ha}^{-1}\right)$ & $5143 \mathrm{~b}$ & $5663 \mathrm{~b}$ & $2693 \mathrm{~b}$ & $3578 \mathrm{~b}$ \\
$\mathrm{~T}_{3}=\mathrm{PM}\left(4 \mathrm{t} \mathrm{ha}^{-1}\right)$ & $5372 \mathrm{a}$ & $5862 \mathrm{a}$ & $2736 \mathrm{ab}$ & $3711 \mathrm{a}$ \\
$\mathrm{T}_{4}=\mathrm{PM}\left(8 \mathrm{t} \mathrm{ha}^{-1}\right)$ & $5178 \mathrm{~b}$ & $5630 \mathrm{~b}$ & $2800 \mathrm{a}$ & $3779 \mathrm{a}$ \\
$\mathrm{SE}( \pm)$ & 35.6 & 39.8 & 21.4 & 30.2 \\
$\mathrm{CV}(\%)$ & 5.12 & 6.23 & 4.56 & 4.23 \\
\hline
\end{tabular}

Same letter in a column represents insignificant difference at $p<0.05$.

$\mathrm{SE}=$ Standard error of means, $\mathrm{CV}=\mathrm{Co}$-efficient of variation.

Table 6. Effect of organic manures on the grain and straw yields of BRRI dhan29 and BINA dhan-8 under saline condition

\begin{tabular}{|c|c|c|c|c|}
\hline \multirow[t]{2}{*}{ Treatment } & \multicolumn{2}{|l|}{ BRRI dhan29 } & \multicolumn{2}{|l|}{ BINA dhan-8 } \\
\hline & Grain yield $\left(\mathrm{kg} \mathrm{ha}^{-1}\right)$ & Straw yield $\left(\mathrm{kg} \mathrm{ha}^{-1}\right)$ & Grain yield $\left(\mathrm{kg} \mathrm{ha}^{-1}\right)$ & Straw yield $\left(\mathrm{kg} \mathrm{ha}^{-1}\right)$ \\
\hline $\mathrm{T}_{0}=$ Control & $2790 c$ & $4576 c$ & $3037 b$ & $3811 b$ \\
\hline $\mathrm{T}_{1}=\mathrm{FYM}\left(5 \mathrm{tha}^{-1}\right)$ & $3666 a$ & $5289 a b$ & $3519 a$ & $4611 a$ \\
\hline $\mathrm{T}_{2^{-}}=\mathrm{FYM}\left(10 \mathrm{tha}^{-1}\right)$ & $3473 b$ & $5246 a b$ & $3602 a$ & $4727 a$ \\
\hline $\mathrm{T}_{3}=\mathrm{PM}\left(4 \mathrm{tha}^{-1}\right)$ & $3490 b$ & $5332 a$ & $3568 a$ & $4763 a$ \\
\hline $\mathrm{T}_{4}=\mathrm{PM}\left(8 \mathrm{tha}^{-1}\right)$ & $3740 a$ & $5074 b$ & $3722 a$ & $4799 a$ \\
\hline $\operatorname{SE}( \pm)$ & 103 & 124 & 133 & 212 \\
\hline CV(\%) & 3.89 & 5.66 & 5.12 & 4.58 \\
\hline
\end{tabular}

Same letter in a column represents insignificant difference at $p<0.05$.

$\mathrm{SE}=\mathrm{Standard}$ error of means, $\mathrm{CV}=\mathrm{Co}$-efficient of variation . 


\section{Grain and straw yields}

Plants exposed with salinity significantly decreased grain yield of four rice varieties. Organic amendments with FYM and PM significantly increased grain yield of all rice varieties (Tables 5 and 6). Salt stress also significantly decreased straw yield of rice varieties whereas organic amendments significantly increased straw yield (Tables 5 and 6 ).

Amanullah et al. (2007) have shown that organic and inorganic amendments enhanced the yield of rice against soil salinity. Shaaban et al. (2013) reported that FYM along with inorganic amendments increased the paddy yield in salt affected soil. Haq et al. (2001) reported that combined application of gypsum, pressmud and FYM produced the highest rice yield in a saline-sodic soil. There are evidences that organic manures reduce the adverse effects of various stresses on plants by affecting the uptake and accumulation of inorganic nutrients (Zaki et al., 2009. Abou El-Magd et al., 2008).

\section{Nutrient uptake by rice}

Soil salinity caused a significant decrease in $\mathrm{N}$ uptake by four rice varieties. Organic amendments significantly increased $\mathrm{N}$ uptake by four rice varieties under salinity condition. Salinity also caused a significant decrease in $\mathrm{P}$ uptake by four rice varieties. Application of FYM and PM increased $\mathrm{P}$ uptake by all rice varieties under salinity condition. Soil salinity caused a significant decrease in $S$ uptake by four rice varieties. Organic amendments increased $\mathrm{S}$ uptake in four rice varieties under salt stress condition (data not shown).

\section{$\mathrm{K}^{+} / \mathrm{Na}^{+}$ratio}

Salinity caused significant decrease in $\mathrm{K}^{+} / \mathrm{Na}^{+}$ratio in both grain and straw of four rice varieties. Application of organic amendments significantly increased $\mathrm{K}^{+} / \mathrm{Na}^{+}$ratio in both grain and straw of all the varieties (data not shown). Similar to our results, Zaki et al. (2009) found that organic manure increased the NPK uptake and vegetative yield under saline conditions. It has been reported that salt stress causes increased uptake of $\mathrm{Na}^{+}$and $\mathrm{Cl}^{-}$, and decreased uptake of essential cations particularly $\mathrm{K}^{+}$(Khan et al., 2003). Similarly, Leithy et al. (2010) conducted an experiment to study the effect of saline water in addition to bio and organic fertilization treatment on geranium plant growth, mineral and chemical constituents. Salinity affected most of the morphological parameters and decreased the growth performance.

\section{Post-harvest properties of saline soils}

The findings also analyzed the post-harvest properties of saline soils. No considerable changes in postharvest soil properties such as $\mathrm{pH}, \mathrm{EC}, \mathrm{CEC}$ and organic matter status were observed by addition of organic manures (data not shown).

\section{CONCLUSIONS}

Soil salinity reduced the growth and yield of four rice varieties. BR-23 variety produced higher yield than local cultivar Mohini in aman season while BINA dhan-8 produced higher yield than BRRI dhan29 in boro season. Organic amendments with both FYM and PM resulted in significant increases in growth and yield of all rice varieties under salinity conditions. Salinity also caused a decrease in nutrient uptake and $\mathrm{K}^{+} / \mathrm{Na}^{+}$ratio in rice. Improved growth and yield of rice by organic amendments were accompanied with increased $\mathrm{K}^{+} / \mathrm{Na}^{+}$ ratio and nutrient uptake under salinity conditions. It can be concluded that organic amendments with FYM and PM confer tolerance to salinity in rice due to increasing nutrient uptake and maintaining higher $\mathrm{K}^{+} / \mathrm{Na}^{+}$ ratio. However, crop cultivation in saline areas might be profitable with organic amendment of soils. Extensive field research work is needed in this area since organic manures like FYM and PM are more available and less expensive.

\section{ACKNOWLEDGEMENTS}

This work was supported by a grant from the Bangladesh Agricultural Research Council. 


\section{REFERENCES}

1. Abou El-Magd MM, Zaki MF, Abou-Hussein SD 2008. Effect of organic manure and different levels of saline irrigation water on growth, green yield and chemical content of sweet fennel. Australian Journal of Basic Applied Science, 2: 90-98.

2. Amanullah MM, Natarajan S, Vanathi D, Ramasamy S, Sathyamoorthi K, 2007. Lowland rice in coastal saline soil. A Review of Agricultural Science Digest, 28: 235-238.

3. FAO 2008: Land and Plant Nutrition Management Service. http://www.fao.org/ag/agl/agll /spush.

4. Gadallah, MS, Mandour MS, 1999. Increasing drought resistance of wheat plants during grain filling by using chemical desiccants. Journal Science of Mansoura University, 25(2): 833-844.

5. Gopal, Dube KS, 2003. Influence of soil and foliar application of potassium on growth, nutrient utilization, yield and quality of sugarcane (Saccharum officinarum L.). New Botanist, 21(1-4): 13-20.

6. Haq I, Khattak SG, Rahman H, Ali A, Salim M, 2001. Effect of various amendments on yield of rice crop under saline-sodic conditions in Mardan/Swabi districts. International Journal of Agricultural Biology, 3: 289-291.

7. Haque S A, 2006. Salinity Problems and Crop production in coastal regions of Bangladesh. Journal of Botany 38:1359-1365.

8. Idrees S, Qureshi MS, Ashraf MY, Hussain M, Naveed NH, 2004. Influence of sulphate of potash (Sop) and farmyard manure (Fym) on sugarcane (Saccharum officinarum L.) grown under salt stress. Journal Life of Social Science, 2: 65-69.

9. IPCC (Intergovernmental Panel on Climate Change), 2007. Climate change 2007: synthesis report. Available at: http://www.ipcc.ch/pdf/assessment-report/ar4/syr/ar4_syr.pdf.

10. Islam MT, Sharma PC, Gautam RK, Singh D, Singh S, Panesar B, Ali S, 2011. Salt tolerance in parental lines of rice hybrids through physiological attributes molecular markers. International Journal of Experimental Agriculture, 2(1): 1-7.

11. Khan AA, Rao SA, McNeilly $T, 2003$. Assessment of salinity tolerance based upon seedling root growth response function in maize (Zea mays L.). Euphytica, 131: 81-89.

12. Khanam M, MM Rahman, MR Islam and MR Islam, 2001. Effect of manures and fertilizers on the growth and yield of BRRI dhan30. Pakistan Journal of Biological Sciences, 4: 172-174.

13. Kibria MG, Islam ABMS, Basak KD, Hossain M, Hoque MA 2015. Assessment of soil fertility and farmer's live style in south-western Bangladesh. Journal of Soil and Nature, 8(3): 1-6.

14. Leithy S, Gaballah MS, Gomaa AM 2010: Associative impact of bio- and organic fertilizers on geranium plants grown under saline conditions. Electronic Journal of Environmental, Agricultural and Food Chemistry 9(3): 617-626.

15. Mahajan S, Tuteja N, 2005. Cold, salinity and drought stresses. An Overview Architecture of Biochemistry and Biophysics, 444:139-158.

16. Mali BS, Thengal SS, Pate PN, 2012. Physico-chemical characteristics of salt affected soil from Barhanpur. Indian Annals of Biological Research, 3: 4091-4093.

17. Miah MA, Panaullah GM, Rahman MS, Ishaque M, 1992. Effect of soil salinity and phosphorus on the growth yield and mineral nutrition of rice. Bangladesh Journal of Rice, 3: 1-5.

18. Momayezi MR, Zahara AR, Hanafi MM, Ismail MR, 2010. Effect of chloride and sulfate salinity on nutrient uptake in Iranian rice (Oryza sativa L.). $19^{\text {th }}$ World Congress of soil science, Soil solutions for a changing world, 1-6 August 2010, Brisbane, Australia. pp. 36-39.

19. Raafat NZ, Tharwat EER, 2011. Improving wheat grain yield and its quality under salinity conditions at a newly reclaimed soil using different organic sources as soil or foliar applications. Journal of Applied Sciences Research, 7: 42-55.

20. Shaaban M, Abid M, Abou-Shanab RAI, 2013. Amelioration of salt affected soils in rice paddy system by application of organic and inorganic amendments. Plant Soil and Environment, 59: 227-233.

21. Shazia I, Muzammil SQ, Muhammad YA, Mumtaz H, Naima HN, 2004. Influence of sulphate of potash (sop) and farmyard manure (fym) on sugarcane (Saccharum officinarum L.) grown under salt stress. Pakistan Journal of Life Science, 1(4): 233-239

22. SRDI, 2010. Saline soils of Bangladesh. SRMAF Project, Ministry of Agriculture, Dhaka, Bangladesh. pp. $1-60$.

23. Zaki MF, Ahmed AA, Singer SM, El -Magd MMA, 2009. Reducing the adverse effect of irrigation water salinity on the vegetative growth, green yield and quality of sweet fennel plants by organic manure. Australian journal of Basic and Applied Science, 3(4): 4449-4464.

24. Zhu JK, 2001. Plant salt tolerance. Trends in Plant Science, 6: 66-71. 